\title{
Universiteit
}

Leiden

The Netherlands

\section{Conjoined questions in Hungarian}

Lipták, A.K.; Boeckx C., Grohmann K.

\section{Citation}

Lipták, A. K. (2003). Conjoined questions in Hungarian. In G. K. Boeckx C. (Ed.), Linguistik aktuell = Linguistics Today (pp. 141-160). Amsterdam: John Benjamins. Retrieved from https://hdl.handle.net/1887/60898

Version: $\quad$ Not Applicable (or Unknown)

License: $\quad$ Leiden University Non-exclusive license

Downloaded from: https://hdl.handle.net/1887/60898

Note: To cite this publication please use the final published version (if applicable). 


\section{Conjoined questions in Hungarian

\author{
Anikó Lipták*
}

Leiden University

\section{Introduction}

In this paper I discuss conjoined multiple questions in Hungarian, which come in two varieties. In one we find conjoined $w h$-items in a preverbal position. In the other variety, we find one $w h$-item in preverbal position and another one or other ones in postverbal position, introduced by a coordinator és "and" element. While other, non-conjoined types of multiple questions have been studied in more detail (see for example Horvath 1986, É.Kiss 1993, Lipták 2001, Surányi 2002), conjoined questions did not receive much attention in the literature. This is presumably due to the fact that these questions easily lend themselves to a superficial analysis in terms of clausal conjunction, followed by ellipsis.

In this paper I will show that the two types of conjoined questions show different syntactic behaviour in many respects. I will argue that the syntactic differences have to be recognized by assigning distinct structural representations for the two types, i.e. a unified analysis for both (as found in Bánréti 1992) is unsatisfactory. The new analyses for these question types will also provide evidence for a binary-branching analysis of coordination.

The structure of this paper is as follows. To set the scene, section 1 introduces multiple questions in Hungarian. Non-conjoined multiple questions will only be mentioned briefly, while conjoined questions will be exemplified in more detail. It will be shown that there are two syntactic types of conjoined questions in Hungarian, depending on whether the coordinator is found in a preverbal or postverbal position. Section 2 will challenge the previous analysis of conjoined questions, which assigned the same structure to both of these questions. Section 3 spells out the fine structure of postverbal conjoined questions, and section 4 makes steps towards a new, adequate analysis for preverbal conjoined questions. Section 5 closes with a summary.

\section{Introduction: multiple questions in Hungarian}

\subsection{Non-conjoined questions}

Hungarian has four types of multiple questions which can be distinguished on the basis of syntactic properties and on the basis of the kind of answer they trigger. For the purposes of the present paper, we can distinguish non-conjoined multiple questions and conjoined questions. Before spelling out the properties of conjoined questions, I briefly summarize what needs to be known about non-conjoined multiple questions.

Non-conjoined questions come in two varieties. In one, all $w h$-items front. The other variety can only involve two $w h$-items, one of which fronts and the other stays in postverbal position. These are demonstrated in the following examples:

(1) $\mathrm{Ki}$ kit látott? multiple fronting multiple question who whomsaw-3SG 'Who saw whom?' 
(2) Ki látott kit? single fronting multiple question who saw-3SG whom

'Who saw whom?'

Multiple fronting questions, like the one in (1), necessarily require a pair-list answer. The linearly non-last $w h$-item or items have to refer to D-linked sets of entities, i.e. they have to refer to a set that both speaker and listener know. According to analyses stemming from É.Kiss (1993), the pair list interpretation is due to the fact that the linearly last and non-last $w h$-items occupy different positions in the structure. More precisely, non-last $w h$-elements occupy Sp,DistP (in the terminology of Beghelli and Stowell 1997) and act as universal quantifiers. The last $w h$-item, similar to any $w h$-item in single questions, sits in Sp,FocP: ${ }^{1}$

(1') [QP Ki [FocP kit látott $[\ldots]]] ? \quad$ multiple fronting

According to an alternative analysis to multiple fronting questions (Surányi 2002), the nonlast elements occupy outer specifiers of FocP and the multiple pair reading derives from absorption.

Single fronting questions ((2) above) correspond to a single pair answer, unless they are formed with melyik "which", in which case multiple pairs can constitute possible answers. These questions can only be used when (a) both $w h$-items are identical (though case-identity is not a requirement), (b) both $w h$-items refer to a D-linked pair of individuals or two Dlinked sets. Current analyses (Horvath 1986, É.Kiss 1993, Lipták 2001, Surányi 2002) agree that the preverbal $w h$-item occupies the unique contrastive focus position in the left periphery, while the postverbal $w h$-item corresponds to a postverbal focused constituent.

\subsection{Conjoined questions}

Conjoined questions come in two types in Hungarian. ${ }^{2}$ In one type, we find the coordinator element between two $w h$-items (3), in the other type between two clauses (4):

a. Ki és mikor látta Marit? preverbal conjunction who-NOM and when saw-3SG Mari-ACC

'Who saw Mari and when?'

b. Mikor és hol láttad Marit? when and where saw-2SG Mari-ACC 'When and where did you see Mari?'

a. Ki látta Marit és mikor? postverbal conjunction who-NOM saw-3SG Mari-ACC and when 'Who saw Mari and when?'

b. Mikor láttad Marit és hol? when saw-2SG Mari-ACC and where 'When and where did you see Mari?'

From now on, I will refer to the first type $(3 a, b)$ as preverbal conjunction and the second one $(4 a, b)$ as postverbal conjunction.

The most notable and theoretically relevant property of Hungarian conjoined questions is that they impose no restriction on the compatibility of $w h$-elements. In preverbal conjoined questions arguments can be conjoined with arguments or adjuncts, without any restriction on their categorial nature. Similarly, any adjunct can be combined with any other adjunct. Hungarian shares this property with Slavic languages as well as Rumanian (Comorovski 1998), (Kazenin 2002): 


$\begin{array}{llll}\text { (5) Kto i začem } & \text { prixodil? } & \text { Russian } \\ \text { who-NOM and what-FOR } & \text { came-3SG } & \\ \text { 'Who came and for what?' } & & \end{array}$

In languages like English or Dutch, however, these sentences are ungrammatical (Browne 1972). In contrast to preverbal conjunction, in Hungarian postverbal conjoined questions (similarly to Russian), the second conjunct can only be an optional wh-element, i.e. an adjunct:

$\begin{array}{llll}\text { (6) a. *Mikor látta Marit és ki? } & \text { Hungarian } \\ \text { when saw-3SG Mari-ACC and who-NOM } & \\ \text { 'Who saw Mari and when?' } & & \\ \text { b. *Začem prixodil i kto? } & \text { Russian } \\ \text { what-FOR came-3SG and who-NOM } & \\ \text { 'Who came and for what?' } & & \end{array}$

Given that categorial and functional identity is required in standard cases of coordination, these facts constitute problems for a syntactic analysis. We will return to them in the following sections.

Before proceeding, note that although conjoined questions are most easily recognized from the presence of a coordinator element, the latter can be phonetically null as well. In this case, however, each $w h$-item has to be pronounced with equally heavy stress (8a) (note that the same lack of overt coordinators is less natural with postverbal conjoined questions, cf. (8b)):

(7) a. 'Kit, 'mikor, 'hol láttál? who-ACC when where saw-2SG 'Whom did you see, where and when?'

b. ?'Kit láttál 'mikor, 'hol? who-ACC saw-2SG when where 'Whom did you see, where and when?'

As far as interpretation is concerned, conjoined questions are interpreted as two separate (conjoined) single questions. (3) and (4), for example, correspond to the logical formula in (8):

(8) $\lambda \mathrm{p}\left[{ }^{\vee} \mathrm{p} \equiv \exists \mathrm{x} \exists\right.$ t. $\mathrm{x}$ sees Mari at $\left.\mathrm{t}\right]$

That is, questions (3) and (4) above ask for identification of the person who saw Mari and the time when this happened, just like (9).

(9) $\mathrm{Ki}$ látta Marit és mikor látta Marit?

who-NOM saw-3SG Mari-ACC and when saw-3SG Mari-ACC

'Who saw Mari, and when did he see Mari?'

Answers to conjoined questions involve a single proposition, in which the constituents corresponding to the $w h$-items are focused:

(10) a. PÉTER látta Marit, TEGNAP.
Péter saw Mari-ACC yesterday
b. PÉTER és TEGNAP látta Marit.
Péter-NOM and yesterday saw-3SG Mari-ACC 
'Péter saw Mari and it happened yesterday.'

The variant in (10a) is the ordinary way of answering conjoined questions, while (10b) is clearly marked: it is used in situations where the answer is surprising or where the focused constituents get special emphasis for one reason or another. Note also that the answer to a conjoined question need not be picked from a specific set of individuals (these questions do not presuppose the existence of a specific, D-linked set).

The two types of conjoined questions that Hungarian possesses have been analyzed as elliptical clausal coordinations (Bánréti 1992) in the following manner $(\varnothing$ stands for elliptical material):

(11) a. [\&P[FocP kinek $\varnothing]$ és [FocP hogyan $V$...] preverbal conj.: forward deletion

b. [\&P[FocP kinek V ...] és [FocP hogyan $\varnothing]$ ] postverbal conj.: backward deletion who-DAT and how

According to (11), conjoined $w h$-phrases in a sentence always result from the coordination of two clauses (FocPs to be precise), with optional but preferred ellipsis in either the first conjunct (in preverbal conjoined questions) or the second conjunct (in postverbal conjoined questions). This analysis places the two question types on parallel grounds, which is attractive. It suggests that except for the difference in the deletion sites the two questions do not differ in anything else.

This conception, however, is wrong. First and foremost, it can be shown that preverbal and postverbal conjoined questions are different constructions with different syntactic structures: it is not the case that all instances of conjoined questions have a multiclausal structure. Rather, we can show on the basis of argument structure and agreement properties that only postverbal conjoined questions do. I will address these points in the next section.

\section{Differences between preverbal and postverbal conjoined questions}

In this section I will point to some important areas in which the two types of conjoined questions clearly show different properties. All these differences will be understood once we analyze preverbal conjoined questions as sentences involving clause internal coordination of $w h$-phrases, and postverbal conjoined questions as instances of clausal coordination accompanied by ellipsis.

\subsubsection{Argument structure}

One clear difference between preverbal and postverbal structures can be found in the way arguments of the verb have to be realized. This can clearly be seen in cases where the $w h$ items correspond to arguments. As I have pointed out in the last section, the postverbal conjunct in conjoined questions cannot license an argument, while the second conjunct in a preverbal conjunction question can:

(12) Ki és kit ölt meg? preverbal coordination who-NOM and who-ACC killed-3SG PV 'Who killed someone and who was it?'
(13) * Ki ölt meg és kit? who-NOM killed-3SG PV and who-ACC 'idem' 
This is in sharp contrast to examples where one of the $w h$-items is an adjunct, as (3) and (4) above demonstrate. The generalization we can draw from these examples is that there is an argument/adjunct asymmetry at hand: postverbal conjoined questions can only contain adjunct $w h$-items in their postverbal position.

The clear grammaticality contrast between (12) and (13) remains unaccounted for if we adopt the analysis in (11), where both types of questions are derived from the same underlying structure, and result in the same LF structures as well ${ }^{3}$ (basing ourselves on the commonly held assumption that elliptical sites are recovered at LF and thereby contribute to semantic interpretation). Bánréti's analysis implies that the two types of conjoined questions are identical at LF:

(14) a. [\&P[FocP ki ölt meg] \& [FocP kit ölt meg] $\quad(=12)$

b. [\&P[FocP ki ölt meg] \& [FocP kit ëlt meg] $] \quad(=13)$

In both clauses in both types of questions, the verbs have a fully saturated argument structure as the Projection Principle requires, which must hold at all levels of representation, including LF. If the pairs have the same LF structures, it is impossible to relate the ungrammaticality of postverbal conjoined questions to the fact that we are dealing with argumental $w h$-phrases, which cannot be missing from clauses according to the Projection Principle. Both (12) and (13) have the following representation after recovery of elided material:

$\begin{array}{llllll}\left(12^{\prime} / 13^{\prime}\right) & {[\mathrm{Ki}} & \text { ölt } & \text { meg }] \text { és } & {[\text { kit }} & \text { ölt meg }] ? \\ & \text { who-NOM } & \text { killed-3SG } & \text { PV and } & \text { who-ACC } & \text { killed-3SG PV }\end{array}$

As it stands, (12/13) violates the Projection Principle, since the first clause only contains a subject, but no overt object. We cannot say that the object term is there, but it is not overt: no covert element can take the position of the object term. The covert object clearly cannot be a trace for lack of a binder.
a. * $* \mathrm{Ki}$ ölt meg $\left.\mathrm{t}_{\mathrm{i}}\right]$ és $\left[\mathrm{kit}_{\mathrm{i}}\right.$ ölt meg pro sub $\left._{\text {f }}\right]$ ?
t: unbound

It cannot be a pro either because pro is only available for definite objects in Hungarian, i.e. known objects, and to have a known object in the first clause which is questioned in the second, is infelicitous: ${ }^{4}$
b. *[Ki ölt meg pro pre $_{\mathrm{i}}\left[\mathrm{kit}_{\mathrm{i}}\right.$ ölt meg pro $\left.{ }_{\text {sub }}\right]$ ?
pro $_{\mathrm{i}}$ : infelicitous

A cataphoric construal of the missing object term is also hard to argue for, because this kind of cataphoric dependency does not exist elsewhere in the grammar. An overt cataphoric prononominal in the same position (16) is ungrammatical:

(15) c. * $*$ Ki ölte meg pro $\left.\mathrm{p}_{\mathrm{i}}\right]$ és $\left[\mathrm{kit}_{\mathrm{i}}\right.$ ölt meg pro $\left.\mathrm{sub}_{\mathrm{su}}\right]$ ?

(16) * Ki ölte meg őt és kit ölt meg? who killed-3SG PV him/she and who killed-3SG PV 'Who killed him/she and who was he/she, whom he killed?'

So a structural representation along the lines of (11) predicts that the sentences in (12/13) should be ungrammatical, because their first clause violates the Projection Principle. This predicts that no conjoined questions should exist with two arguments in them.

However, only postverbal conjoined questions are ungrammatical under these circumstances. This proves that the representation in (12/13) is correct for postverbal conjoined questions, but is wrong for preverbal ones. Postverbal conjoined questions are indeed conjoined single questions with ellipsis in the second conjunct. Preverbal conjoined 
questions, however, are not conjoined clauses, but contain only one clause, in which all whphrases belong to one and the same verb. This way there is no violation of the Projection Principle, since all arguments are present in the clause.

$$
\text { [FocP[\&PKi és kit] ölt meg]? }
$$

The importance of facts like (12) and (13) has not been recognized so far in the literature on Hungarian, presumably because of prevailing studies on adjunct questions or verbs which can be interpreted both transitively and intransitively, like read. But even in the latter case, (18) has a different meaning from (19), as I indicate in the English translations:

$$
\begin{aligned}
& \mathrm{Ki} \text { és mit olvasott? } \\
& \text { who-NOM and what-ACC read-3SG } \\
& \text { 'Who has read something and what was it?' } \\
& \mathrm{Ki} \text { olvasott és mit? } \\
& \text { who-NOM read-3SG and what-ACC } \\
& \text { 'Who was engaged in reading and what was he reading?' }
\end{aligned}
$$

\subsubsection{Agreement properties}

The other difference between preverbal and postverbal conjoined questions can be observed in the agreement properties of the base verb. The difference in agreement also suggests that in preverbal conjoined questions all $w h$-arguments belong to the same verb. Consider the following full (non-elided) clausal coordination:

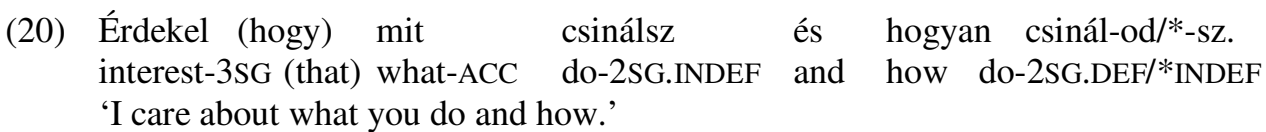

Definiteness agreement in the second conjunct is obligatory; given that the object is pro, definite agreement results. If (20) is turned into a preverbal conjoined structure by deleting the verb in the first conjunct, the result is expected to show the same agreement in the second conjunct, since that is not affected in any way by the ellipsis in the first. But this expectation is false, the grammatical sentence has the unexpected indefinite conjugation in the second conjunct:

$$
\begin{aligned}
& \text { Érdekel (hogy) mit és hogyan csinál-sz/*-od. } \\
& \text { interest-3SG (that) what-ACC and how do-2SG.INDEF/*DEF } \\
& \text { 'I care about what you do and how.' }
\end{aligned}
$$

This can only be the case if the verb in (21) agrees with mit 'what', which is an indefinite pronoun in Hungarian. This indicates that (21) is not derived by means of ellipsis, but rather, both $w h$-items are constituents of the same (and only) embedded clause, i.e. the verb has mit as its complement.

\subsubsection{The structural representation of conjoined questions}

In the last two sections I have listed some arguments to the effect that preverbal conjoined questions are real multiple questions in the sense that we find more than one $w h$-phrase in a single clause in them. All conjoined $w h$-items are in one and the same clause. Postverbal conjoined questions on the other hand are multiple clausal structures, the result of clausal coordination followed by ellipsis. The right structural representations are given in (22): 
(22) a. Preverbal coordination: [FocP $\left.\left[\mathrm{wh}_{1} \& \mathrm{wh}_{2}\right] \mathrm{V}\right]$

b. Postverbal coordination: [FocP $\left.\mathrm{wh}_{1} \mathrm{~V}\right] \&\left[\mathrm{FocP}_{\mathrm{Wh}} \varnothing\right]$

Thus, in fact postverbal conjoined questions do not fall under multiple questions, since they involve multiple clauses with one single question in each. This means that these questions have the syntax of single questions, while preverbal conjoined questions clearly contain multiple instances of $w h$-items in the same clause. Interestingly, exactly the same conclusion is drawn about Russian conjoined questions by Kazenin (2002).

It is important to note that this syntactic difference between preverbal and postverbal coordinations does not carry over to the interpretive level (which is why the syntactic difference is not so easily perceived). Both types of conjoined questions are the same semantically: they are used in the same situations, they elicit the same answers, i.e. they are functionally equivalent. Functionally speaking, they exist because other multiple questions cannot be used under circumstances where the speaker expects a single-pair answer: Hungarian multiple fronting questions can never be used when a single-pair answer is expected, and although single fronting multiple questions can, these are restricted to categorially identical $w h$-items (see section 1 above). Thus, conjoined questions are the only means to ask a multiple question where the $w h$-items are not of the same category and where the speaker expects a single-pair answer. Note that when the same content can be expressed with a single fronting multiple question (because the $w h$-items are categorially identical), conjoined questions are strange (Kálmán et al. 2001):
a. ??Ki és kibe botlott bele? conjoined question who-NOM and who-INTO bumped-3SG into
b. $\mathrm{Ki}$ botlott bele kibe?
who-NOM bumped-3sGinto who-INTO
'Who bumped into whom?'

The marginality of (23) can thus be given a functional explanation: the use of a coordinator element is marginal if the conjunction-less counterpart of the same sentence would be grammatical. This recalls the 'Avoid Conjunction Principle' ("if no conjunction marker is necessary, do not use any") by Progovac (1999).

\section{The fine structure of postverbal conjoined questions}

The previous section has shown that postverbal conjoined questions in Hungarian are best analyzed in terms of coordination of clausal material. To spell this out in some more detail, we have to find answer to several important questions.

First of all, what kind of clausal category are we dealing with in these constructions? Second, how can we represent conjunction structurally? Third, what kind of ellipsis affects the second clause in these questions? I will answer these questions in turn, starting with the last one.

It can be easily seen that the ellipsis found in postverbal conjoined questions is not a runof-the-mill VP ellipsis. First of all, the missing sequence in these questions corresponds to a larger structure than VP: it actually corresponds to Foc'. Recall that in sentences with focused constituents the verb raises up to Foc $^{0}$. Under the common view that holds that ellipsis requires parallelism, this must mean that the structure affected by ellipsis in the second conjunct is a Foc' category as well. Also, postverbal conjoined questions clearly differ from VP-ellipsis in that in the latter but not in the former the two clauses can refer to two distinct events: 
This interpretation, however, is excluded in the case of conjoined questions: they always refer to the same event:

(25) Ki látta Marit és mikor? who-NOM saw-3SG Mari-ACC and when 'Who saw Mari and when was this?'/'Who saw Mari once and when did he see her another time?'

In this, a postverbal conjoined question patterns together with conjunction reduction, which is also impossible to interpret as referring to two distinct events:

(26) Péter elment, mégpedig pénz nélkül. conjunction reduction Peter left and money without 'Peter left, and/moreover without money.'

This also shows (among other things) that postverbal conjoined questions are actually a case of conjunction reduction. ${ }^{5}$

Given the size of the elided material in these constructions it is not at all surprising that they denote one single event. It is clear that what gets affected by deletion in the second conjunct actually involves the event-argument as well (on a Davidsonian view, and assuming that the event argument is syntactically represented). The parallelism requirement explains why the event in the second conjunct necessarily has to be anaphoric.

Let us proceed to finalize the structural representation of the conjunction and the conjoined items. At first blush it seems that the representation we have arrived at by arguing for a deletion process affecting Foc' in the second clause cannot be on the right track, for want of a licenser for the subject trace:

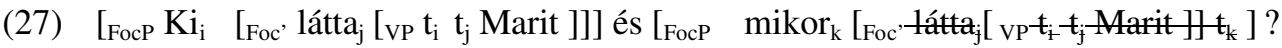
who-NOM saw-3SG Mari-ACC and when

As it stands, in this representation of (27) the second clause contains an unbound subject trace. This problem, however, vanishes once we take the view that specifiers c-command out of their maximal category. Evidence for this comes from the following cases of pronominal binding:
a. $\mathrm{Ki}$
beszélt és
melyik barátjáról?
who-NOM talked-3SG and which pro friend-POSS.3SG-ABOUT
'Who talked and about which friend of his?'
b. *Melyik barátja beszélt és kiről? which pro friend-POSS.3SG-NOM talked-3SG and who-ABOUT talked-3SG

This shows on the one hand that the first $w h$-item can c-command out of its clause, but it also shows that there is an asymmetric relationship between the two conjuncts: the $w h$-item in the second conjunct does not c-command the first. This provides primary evidence for an X-bar theoretic approach to coordination (Johannessen 1998, Munn 1993), which predicts an asymmetric relation between conjuncts: the first conjunct c-commands the second, but not vice versa. These facts help to answer the questions concerning the representation of postverbal conjoined questions. The conjoined clauses in Hungarian postverbal conjoined questions are:

a.) FocP constituents (otherwise, if they were larger, the $w h$-item in Sp,FocP could not ccommand out of them) 
b.) in an asymmetric relation (which provides evidence for the X-bar theoretic approach to coordination)

Adopting the view in which coordination is adjunction of a coordination phrase to a category (Munn 1993), we arrive at the following representation of postverbal conjoined questions:

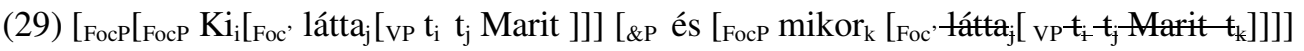

The focused $k i$ "who" c-commands out of its FocP and thus it licenses its trace both in the first conjunct as well the second conjunct. Ellipsis affects the second conjunct under identity with the elements in the first one.

The fact that the antecedent Foc' and the elided Foc' do not coincide completely is not unique to conjoined questions and conjunction reduction. As has been noticed by Chung, Ladusaw and McCloskey (1995), other instances of ellipsis, like IP-ellipsis also have this property:

(30) John likes Mary. I don’t know why [John likes Mary t ].

Chung, Ladusaw and McCloskey suggest a "sprouting" mechanism that adds the missing empty category to the recycled IP at LF.

Summarizing, I have argued that postverbal conjoined questions should be assigned the representation in (29). They involve the conjunction of two clausal categories, Foc'-s to be precise, with deletion of phonetic material in the second conjunct. The arguments presented in this section provided evidence for an X-bar theoretic approach to coordination as well.

\section{Towards the correct analysis of preverbal conjoined questions}

In section 2 we established that preverbal conjoined questions involve coordination of $w h$-phrases. This claim faces a very serious problem, which Bánréti (1992) did not encounter: how can categorially distinct items be conjoined? In most usual cases of coordination the category of the coordinates must be the same together with their theta-roles if they have any. This is the so-called "Law of Coordination of Likes" (Williams 1981):

(31) *I helped Peter and quickly.

$[\mathrm{NP} \& \mathrm{AP}]$

Before trying to tackle the problem preverbal conjoined questions present for this law, I will start out by showing that $w h$-items are not the only constituents that defy the Law of Coordination of Likes. Quantificational items also do. Some speculations as to how this is possible and what syntactic consequences this has, will be discussed in section 4.2.

\subsection{Clause internal coordination in preverbal conjoined questions: parallels with quantifiers}

The Law of Coordination of Likes tolerates a great many exceptions even in English. One frequent example of unlike category coordination can be found when the coordinates have predicative function, well-described and analyzed in Sag et al. (1985):

(32) Pat is either stupid or a liar.

$[\mathrm{AP} \& \mathrm{NP}]$

The other type, more closely related to the Hungarian coordination facts, can be found in many languages including English:

(33) John met Mary and in her house!

$[\mathrm{NP} \& \mathrm{PP}]$ 
This example of unlike category coordination is licensed only if both coordinates are emphasized, and the sentence describes an unexpected state of affairs (indicated here by the exclamation mark). In a vein similar to the Hungarian examples, English can coordinate $w h$ items due to their "equal status [...] AS wh WORDS" (Bolinger 1978):

(34) When and how did it happen?

It seems to be true across languages that emphatic operators are by and large conjoinable regardless of their different categorial status, although languages do differ as to what kind of quantifiers and environments are allowed. Hungarian is a language where all kinds of quantifiers can be conjoined within a clause, provided they are stressed (marked by '):

(35) Ide 'mindenki és 'mindig bejöhet.

here everyone-NOM and always PV-come-POT-3SG

'Everyone can enter here and this holds for all times.'

(36) Ide 'bárki és 'bárkit meghívhat.

here anyone-NOM and anyone-ACC PV-invite-POT-3SG

'Anyone can invite anyone here.'

(37) Ide 'senki és 'semmikor nem jöhet be.

here no-one-NOMand never not come-POT-3SG PV

'No-one can enter here and this holds for all times.'

Similar examples, involving negative polarity items, can be found in Russian and other Slavic languages (Kazenin 2002).

The conclusion we can draw is that emphatic stress makes categorial differences invisible: the $[\& \mathrm{P}[\mathrm{XP}] \&[\mathrm{YP}]]$ pattern is available for clause-internal coordination as long as both $\mathrm{XP}$ and YP carry emphatic stress. One way of interpreting this pattern would be to say that for certain mechanisms emphatic quantifiers are recognized as items with a common ' $Q$ '

category/function ${ }^{6}$, and therefore can be conjoined with any item with a similar ' $Q$ ' category/function. This is reminiscent in a way of what was observed in (32/33): there it was shown that unlike categories with the same predicative function can also coordinate. This shows that for coordination, it is not only the syntactic category of the coordinates that counts.

\subsection{A possible derivation of preverbal conjoined questions}

The previous section has shown that clause-internal coordination of unlike categories is not restricted to $w h$-elements: the scope of elements that can occur in this construction is broader: it involves quantificational/emphatic elements in general, at least in Hungarian. To account for this pattern, however, is really difficult. There are many questions that one would need to answer before the final picture about these constructions can be pieced together. What is the fine structure of the coordination phrase? How is this formed? How are the traces of the coordinated items licensed? Unfortunately, I cannot provide definitive answers to all these questions, due to serious lack of understanding concerning coordination phrases in general. Pending further research in this area, here I only sketch the directions a future satisfactory analysis should take. As we will see, preverbal conjunctions have many contradictory properties.

Let us start with the representation of the coordination phrase. If the argumentation in the previous section is on the right track, we have evidence for an X-bar approach to coordination in Hungarian conjoined questions in particular, and hopefully to coordination in general. Adopting the structure I used in the previous section (Munn 1993), this means that preverbal questions have the following structure: 


$$
\begin{array}{llll}
\text { [FocP[whPkinek } & {[\& P} & \text { és } & \text { hogyan }_{j} \text { ] segítettél } t_{i} t_{j} \\
\text { who-DAT } & & \text { and how helped-2SG }
\end{array}
$$

That is, the second $w h$-item is an adjoined coordination phrase (\&P) to the first $w h$-item, and the whole complex (whose external distribution is that of a $w h$-item) occupies the Sp,FocP position, as any single $w h$-item does in Hungarian. This analysis predicts that we find asymmetries between the conjoined $w h$-items. These asymmetries are indeed present, supporting the representation in (38): there is an asymmetric c-command relation between the two $w h$-items. The first, but not the second, c-commands the other:
a. $\mathrm{Ki}$
és melyik barátjáról
beszélt?
who-NOM and which pro friend-POSS.3sG-ABOUT
talked-3SG
'Who talked and about which friend of his?'
b. *Melyik barátja
és kiröl
beszélt?
which pro friend-POSS.3SG-NOM and who-ABOUT talked-3SG

This is exactly what we get with other quantifiers as well, further strengthening the parallelism found in section 4.1 between the two:
a. Senki és semelyik barátjáról noone-NOM and none pro friend-POSS.3SG-ABOUT not talked-3SG 'Noone talked about any friend of his.'
b. *Semelyik barátja és senkiröl nem beszélt. none pro friend-POSS.3SG-NOM and noone-ABOUT not talked-3SG

This basic asymmetry clearly refutes other, non-X-bar theoretic approaches to the coordination structures under study (such as the 3-dimensional representations in which coordinates are equal in structural terms, as in Goodall 1987, van Riemsdijk 1998). These approaches would not predict any asymmetries between the $w h$-items, contrary to fact.

Given this, we can address the question of how the traces of the individual $w h$-items are licensed. It is easy to argue that the first $w h$-item c-commands out of the coordination complex, and as such it c-commands its trace lower in the structure. It is not clear, however, whether the second $w h$-item can do the same, although claims to this effect can be found in the literature. Zoener (1995) argues that the following disjoint reference effect is to be explained as a Principle B violation, due to the fact that the second conjunct c-commands the pronominal:

(41) *[Robin and Paul $\left._{\mathrm{j}}\right]$ like him $\mathrm{j}_{\mathrm{j}}$

It seems to me, however, that (41) is inconclusive to arrive at this conclusion, because it wrongly predicts that an anaphor in the place of the pronominal is grammatical:

$$
*\left[\text { Robin and } \text { Paul }_{\mathrm{j}}\right] \text { like himself } \mathrm{j} \text {. }
$$

So examples of A-binding seems to be unavailable to illustrate this point. Other examples, involving bound-pronominal interpretation, however, can illustrate this better:

(43) [Standing on the stairs and with every boy present] the headmaster gave them their books.

A bound pronominal interpretation seems to be available in (43), which indicates that the universal quantifier has scope over the whole clause. Note that in (43) we are also dealing with unlike category coordination, just like in the case of conjoined questions. 
At this point it is difficult to make any claims as to how (43) is possible, whether it is due to feature percolation from the second conjunct to the whole coordination phrase or to some special mechanism. The behaviour of the two conjuncts is to some extent contradictory: on the one hand there is clear asymmetry between them (cf. 40), on the other, they are equal in scope taking. I leave the resolution of this contradiction for further research.

Another problem we run into when analyzing preverbal conjoined questions is the formation of the coordinate structure itself. A representational approach to the coordination phrase would be more convenient, however, there is one aspect of these constructions, which would rather prefer a derivational account: superiority, another asymmetry between the whitems. As Kálmán et al. (2001) also notes, there are ordering requirements between the conjoined $w h$-items in questions: ${ }^{7}$
a. Ki és kiröl beszélt?
who-NOM and who-ABOUT talked-3SG 'Who talked and about whom?'
b. ???Kiröl és ki beszélt?
who-ABOUT and who-NOM talked-3SG

While superiority is very clearly present in Hungarian, lack of superiority effects has been reported about Russian (Kazenin 2002). And although I cannot contest Kazenin's judgements about Russian, other Slavic languages pattern with Hungarian in that they do exhibit superiority in preverbal conjoined questions (Olga Tomič, p.c.):
a. Koj i kade odi? where and who-NOM go-3SG
b. ??Kade i koj odi?
'Who goes and where?'

These facts reinforce the view that the first conjunct is more distinguished than the second, and they prefer a derivational account. Superiority facts are currently handled in the derivational frame, and accounted for by "attract the highest". It could be argued therefore that what gets attracted by the $\mathrm{Foc}^{0}$ head first is the first conjunct, and that the second conjunct, in the form of a \&P adjunct, gets adjoined to it later, post-cyclically (recalling the spirit, but not the content of proposals like Fox 2002, Stepanov 2001 concerning the theoretical possibility of late adjunction). If this account is viable, it provides evidence for the $\mathrm{X}$-bar theoretic and derivational approach to coordination.

\section{Summary}

This paper made an attempt to achieve a better understanding of conjunction possibilities of Hungarian question words and quantifiers. It showed that there are two distinct patterns in which these items can take part, and that these two patterns cannot be lumped together under a uniform syntactic analysis. Although the definitive analysis of the preverbal conjunction pattern is still not in sight, we can be reasonably sure that it involves a single coordination phrase within one and the same clause. Postverbal conjunctions, however, necessarily have to receive a multiclausal analysis in which ellipsis is operative. As an auxiliary result of this investigation, the facts provided evidence for an X-bar theoretic approach to coordination. 


\section{Notes}

* The production of this article was supported by a grant from the Netherlands Organization for Scientific Research (NWO). The gist of the ideas presented in section 2 originate from Lipták (2000) and (2001). For discussions on the present topic I am indebted to Jeroen van Craenenbroeck, Marcel den Dikken, Johan Rooryck and Luis Vicente. All errors and shortcomings are mine.

1. Note that the position of the finite verb is $\operatorname{Foc}^{0}$ in sentences containing a focused element.

2. In this paper I do not consider questions with a disjunction between two wh-elements:

(i) Kit vagy mit láttál?

whom or what-ACC saw-2SG

'Who or what did you see?'

In these questions the conjoined $w h$-items always have to be categorially identical, which is not the case with questions where $w h$-items are coordinated by an 'and' coordinator.

3. Including the possibility that either type is derived from another. One could imagine that the postverbal pattern is derived via the extraposition of és kit - this, however, can be safely excluded not only because in this case, (13) would be expected to be grammatical, just like (12), but also because Hungarian does not allow for conjunct-extraposition in any context, evidenced by the following:

(i) a. Mari és Péter a birák. Mari and Péter the judge-PL 'Mari and Péter are the judges.'

b. *Mari a birák és Péter. Mari the judge-PL and Péter

4. If (14b) were grammatical, it would occur with definite conjunction on the first verb due to the fact that object pro is a definite item. However, even definite conjugation on the verb does not make the sentence better:
(i) * Ki
ölte meg pro $_{\text {obj }}$ és kit
who-NOM killed-3SG.DEF PV and who-ACC killed-3SG.INDEF PV
ölt meg pro sub $_{\text {sub }}$ ?

5. Kazenin (2002) treats postverbal conjoined questions as an instance of sluicing - a move I would not subscribe to. In some (albeit special) cases of sluicing anaphoricity of the events is not required:

(i) I know John went to the party, but I do not know who else.

6. One might take recourse to an account where emphatic constituents instantiate a distinguished, e.g. EmphP category. This way, the caterogial identity problem would be resolved.

7. Although the strength of the ordering restriction is dependent on stress assignment: heavily stressed $w h$-items can appear in any order.

\section{References}

Bánréti, Z. 1992. “A mellérendelés.” In Strukturális magyar nyelvtan I. Mondattan, F. Kiefer (ed.), 715-796. Budapest: Akadémiai Kiadó.

Beghelli, F. \& Stowell, T. 1997. "Distributivity and Negation." In Ways of scope taking, A. Szabolcsi (ed.), 71-107. Dordrecht, Reidel. 
Bolinger, D. 1978. “Asking more than one thing at a time.” In Questions, Hiż, H. (ed.), 107150. Dordrecht, Reidel.

Browne, W. 1972. "Conjoined Question Words and the Limitation on English Surface Structure." Linguistic Inquiry 3: 223-226.

Chung, S., W.A. Ladusaw, and J. McCloskey 1995. "Sluicing and Logical Form." Natural Language Semantics 3: 239-282.

Comorovski, I. 1989. Discourse and the syntax of multiple constituent questions. Doctoral Dissertation, Cornell University.

Fiengo, R. and R. May 1994. Indices and Identity. [Linguistic Inquiry Monograph 24]. Cambridge (MA): MIT Press.

Fox, D. 2002. "Antecedent-Contained Deletion and the Copy Theory of Movement." Linguistic Inquiry 33: 63-96.

Goodall, G. 1987. Parallel Structures in Syntax. Coordination, Causatives and Restructuring. Cambridge: Cambridge University Press.

Horvath, J. 1986. Focus in the Theory of Grammar and the Structure of Hungarian. Dordrecht: Foris.

Johannessen, J. 1998. Coordination. Oxford: Oxford University Press.

Kálmán, L. (ed.) 2001. Magyar leíró nyelvtan. Mondattan 1. Budapest: Tinta Könyvkiadó.

Kazenin, I. K. 2002. "On coordination of $w h$-phrases in Russian.” Ms. University of Tübingen/University of Moscow.

É. Kiss, K. 1993. "Wh-movement and specificity.” Natural Language and Linguistic Theory 11: $83-120$.

Lipták, A. 2000. "Multiple relatives as relatives of questions.” In Approaches to Hungarian 7, G. Alberti and I. Kenesei (eds), 151-177. Szeged: JATE Press.

Lipták, A. 2001. On the syntax of wh-items in Hungarian. Doctoral Dissertation, Leiden University.

Munn, A. 1993. Topics in the syntax and semantics of coordinate phrases. Dissertation. University of Maryland.

Progovac, L. 1999. "Conjunction doubling and 'Avoid Coordination Principle'." In Topics in South Slavic Syntax and Semantics [Current issues in Linguistic Theory, 1/2], M.Dimitrova-Vulchanova and L. Hellan (eds), 25-39. Amsterdam, John Benjamins.

Riemsdijk, H. van 1998. "Trees and Scions - Science and trees." Chomsky $70^{\text {th }}$ Birthday Celebration Fest-Web-Page: http://mitpress.mit.edu/chomskydisc/riemsdyk.html.

Sag, I., G. Gazdar, Th. Wasow \& S. Weisler 1985. "Coordination and how to distinguish categories." Natural Language and Linguistic Theory 3: 117-171.

Stepanov, A. 2001. "Late Adjunction and Minimalist Phrase Structure." Syntax 4 (2): 94-125. Surányi, B. 2002. "Multiple $w h$-fronting and $w h$-in-situ in Hungarian and choice functions." Talk presented at the Sixth International Conference on the Structure of Hungarian, 12-13 September, Düsseldorf.

Wilder, Ch. 1997. "Some properties of ellipsis in coordination." In Studies on Universal Grammar and Typological Variation, A. Alexiadou and T. A. Hall (eds), 59-107. Amsterdam: John Benjamins.

Williams, E. 1981. “Transformationless Grammar.” Linguistic Inquiry 17: 645-653.

Zoener, E. 1995. Coordination: The syntax of \&P. Doctoral Dissertation, Cornell University. 